\title{
Effect of Growth Temperature on the Lipid Composition of two Strains of Thermus sp.
}

\author{
By ADELINA PRADO, $\uparrow$ MILTON S. DA COSTA* AND \\ VITOR M. C. MADEIRA \\ Centro de Biologia Celular, Universidade de Coimbra, 3049 Coimbra Codex, Portugal
}

(Received 29 January 1988)

Growth-temperature-dependent alterations in the total extractable lipid and polar lipid components of two strains of Thermus sp. isolated from a Portuguese hot spring were studied between $50^{\circ} \mathrm{C}$ and $78^{\circ} \mathrm{C}$. The total extractable lipid varied between 8.0 and $10.6 \%$ of the cell dry weight; there were no alterations in the phosphorus and carotenoid content of the lipid extract, but the carbohydrate content increased as the growth temperature was raised. Three glycolipids and the four phospholipids were separated by thin-layer chromatography. The relative concentration of the major glycolipid $\left(\mathrm{GL}_{1}\right)$ of strain SPS 17 (yellow-pigmented) increased with the growth temperature, whereas the relative concentration of a minor glycolipid $\left(G_{2}\right)$ decreased. There were no temperature-dependent alterations in the relative concentrations of $\mathrm{GL}_{1}$ and $\mathrm{GL}_{2}$ from strain SPS 11 (colourless). The proportion of the major phospholipid ( $\left.\mathrm{PL}_{2}\right)$ decreased in both strains as the growth temperature increased, whereas that of a minor phospholipid $\left(\mathrm{PL}_{1}\right)$ increased. The major fatty acyl chains of both strains were 13methyltetradecanoate (iso- $\mathrm{C}_{15}$ ) and 15-methylhexadecanoate (iso- $\mathrm{C}_{17}$ ). The $\mathrm{GL}_{1}$ in strains SPS 11 and SPS 17 had a glucose : glucosamine : glycerol:long fatty acyl chain ratio of $3: 1: 1: 3$.

\section{INTRODUCTION}

Many thermophilic eubacteria, assigned to the genus Thermus, have been isolated from natural and man-made thermal environments since Brock \& Freeze (1969) described the type species, T. aquaticus strain YT-1 (Pask-Hughes \& Williams, 1977; Hudson et al., 1986). These strains are normally yellow pigmented but some are colourless; they have an optimum growth temperature of $70-75^{\circ} \mathrm{C}$. Another species, $T$. ruber, with a lower growth temperature $\left(60^{\circ} \mathrm{C}\right)$ was described by Loginova et al. (1984).

The polar lipid fraction of five yellow-pigmented and colourless strains that have been studied contains a major glycolipid and a major phospholipid (glycophospholipid). The major glycolipid is a diacyl-diglycosyl-( $N$-acyl)glycosaminylglucosylglycerol which, depending on the strain, contains glucose, or glucose and galactose, and glucosamine or galactosamine (Oshima \& Yamakawa, 1974; Pask-Hughes \& Shaw, 1982). Branched fatty acyl chains $\left(C_{15}\right.$ and $\left.C_{17}\right)$ comprise the major aliphatic moieties of the polar lipids of these strains (Ray et al., 1971 a; Oshima \& Yamakawa, 1974; Oshima, 1978; Pask-Hughes \& Shaw, 1982). The effect of the growth temperature on the fatty acyl composition of strains YT-1 and HB-8 has been studied in detail, but little attention has been paid to growth-temperature-dependent alterations in other lipid components.

This paper describes the effect of the growth temperature on the total and polar lipid content of two strains of Thermus sp. isolated from a Portuguese thermal spring and provides a preliminary analysis of the major glycolipids in both strains.

† Present address: Departamento de Bioquímica, Facultad de Ciencias, Universidad del País Vasco, 48080 Bilbao, Spain. 


\section{METHODS}

Organisms and growth conditions. Thermus sp. strains SPS 11 and SPS 17, isolated from the São Pedro do Sul Spa in central Portugal (unpublished results), were maintained at $-80^{\circ} \mathrm{C}$ in Thermus medium (Brock, 1978) containing $15 \%(\mathrm{v} / \mathrm{v})$ glycerol. Liquid cultures were grown in 1 litre Erlenmeyer flasks containing $200 \mathrm{ml}$ Thermus medium at temperatures between $50^{\circ} \mathrm{C}$ and $78{ }^{\circ} \mathrm{C}$ in a water-bath shaker (New Brunswick, RW-650) at 120 r.p.m. For larger cell masses, the strains were grown in a 251 fermenter (New Brunswick, MF-1285) at $72{ }^{\circ} \mathrm{C}$ until late exponential growth phase.

Extraction and separation of lipids. Freshly harvested cells were extracted twice by the method of Bligh \& Dyer (1959) and the extract was washed once with $0.5 \mathrm{M}-\mathrm{KCl}$ to induce phase partition and remove non-lipid impurities (Ray et al., $1971 b$ ). The polar lipids were separated from the neutral lipid fraction containing the vast majority of the carotenoids on preparative silica gel $\mathrm{G}$ plates ( $2 \mathrm{~mm}$ thickness, Merck) developed with acetone. The neutral lipids and the carotenoids migrated with the solvent front, whereas the polar lipids remained at the origin. This fraction was eluted from the silica with chloroform/methanol/water $(45: 45: 10$, by vol.).

The individual polar lipids were separated by thin-layer chromatography (TLC) on silica gel G plates $(0 \cdot 25 \mathrm{~mm}$ thickness, Merck) with solvent systems consisting of chloroform/methanol/ammonia (25\%)/water $(70: 30: 4: 1$, by vol.) (solvent $A)$ or chloroform/methanol/water $(65: 25: 4$, by vol.) (solvent $B$ ). The glycolipids and phospholipids were eluted from the silica developed with solvent $A$ as described above, after spraying the plates with water to locate the lipid-containing areas. Further purification of the major glycolipids was done by TLC with solvent B. The purity of the glycolipids was confirmed by two-dimensional TLC using chloroform/methanol/ammonia $(25 \%) /$ water $(65: 35: 0 \cdot 3: 4$, by vol.) as a solvent system in the first dimension and chloroform/methanol/acetone/ acetic acid/water $(50: 20: 10: 10: 5$, by vol.) in the second dimension.

Analytical methods. The dry weight of the cells was determined before extraction by passing a sample of the suspension through a pre-weighed dry Sartorius type SM membrane filter $(0.45 \mu \mathrm{m}$, pore size $)$ and drying at $80^{\circ} \mathrm{C}$ to constant weight. The weight of the total lipid extract was determined gravimetrically on very small tared dry aluminium foil pans. The carotenoids were estimated by the absorption peak at $455 \mathrm{~nm}$.

The polar lipids were visualized on the TLC plates using iodine vapour; phosphorus, carbohydrate and free amino groups were detected using the Dittmer-Lester reagent, $\alpha$-naphthol and ninhydrin respectively (Christie, 1982). The phosphorus content of the total lipid extract, polar lipid fraction and individual polar lipids was determined using the Bartlett (1959) modification of the Fiske and Subbarow method after hydrolysis of samples at $180{ }^{\circ} \mathrm{C}$ in $70 \% \mathrm{HClO}_{4}$ (Bottcher et al., 1961). The total carbohydrate of the same lipid fractions was determined using the phenol/sulphuric acid method (Dubois et al., 1956).

Samples of the major glycolipids were hydrolysed under $\mathrm{N}_{2}$ in $2 \mathrm{M}-\mathrm{HCl}$ at $100^{\circ} \mathrm{C}$ for $3 \mathrm{~h}$ in sealed ampoules. The hydrolysates were extracted three times with light petroleum (b.p. $40-60^{\circ} \mathrm{C}$ ) to recover fatty acids. The aqueous phase was neutralized with $\mathrm{NaOH}$, and the free sugars and glycerol separated by descending paper chromatography on Schleicher and Schuell no. 2043 paper using a solvent system of ethyl acetate/pyridine/acetic acid/water ( $5: 5: 1: 3$, by vol.). The components were visualized with alkaline silver nitrate (MacLean \& Scott, 1976) and with ninhydrin.

The total carbohydrate in the aqueous phase was determined using the phenol/sulphuric acid method, D-glucose with glucose oxidase (Sigma), total polyol using the method of Bok \& Demain (1977), glycerol with glycerol kinase (Sigma) and glucosamine using the Elson and Morgan procedure (Dittmer \& Wells, 1969). Sugars and glycerol hydrolysed under the same conditions were used as standards.

Fatty acid methyl esters were prepared with $14 \%(\mathrm{v} / \mathrm{v})$ boron trifluoride-methanol (Dittmer \& Wells, 1969) using phosphatidylcholine as a standard. Gas liquid chromatography (GLC) was done using a Varian Aerograph gas chromatograph (model 2700) with a flame ionization detector. An open tubular capillary column SP-2340 ( $25 \%$ methyl, $75 \%$ cyanopropyl silicone, $0.2 \mu \mathrm{m}$ phase thickness, $60 \mathrm{~m} \times 0.75 \mathrm{~mm}$ i.d.) was eluted with $\mathrm{N}_{2}$ at $4 \mathrm{ml}$ $\mathrm{min}^{-1}$, and operated at $160{ }^{\circ} \mathrm{C}$. Some separations were confirmed with a $4 \mathrm{~m} \times 3.2 \mathrm{~mm}$ i.d., column packed with $10 \%$ SP-2340 ( $25 \%$ methyl, $75 \%$ cyanopropyl silicone) on Chromosorb WAW 100/120 mesh eluted with $\mathrm{N}_{2}$ at $6.7 \mathrm{ml} \mathrm{min} \mathrm{m}^{-1}$ and operated at $145^{\circ} \mathrm{C}$. Fatty acid methyl esters were identified by comparison of their retention times with those of known standards.

Infrared spectrophotometry was done on samples applied in $\mathrm{KBr}$ discs using a Perkin-Elmer (model 1430) spectrophotometer.

\section{RESULTS}

\section{Effect of growth temperature on the total lipid extract}

Strain SPS 17 (yellow) was grown between $50^{\circ} \mathrm{C}$ and $78^{\circ} \mathrm{C}$, whereas strain SPS 11 (colourless) could only be grown up to $75^{\circ} \mathrm{C}$. The total lipid content of both strains varied between about 8.0 and $10.6 \%$ of the cell dry weight (Table 1 ). There appeared to be only a very slight increase in the total lipid extract as the growth temperature was raised. The phosphorus content of the lipid 
Table 1. Effect of growth temperature and growth phase on the total lipid composition of Thermus SPS 11 and SPS 17

Values without error terms are from a single determination; other values are the means \pm SD of the number of experiments indicated in parentheses.

\begin{tabular}{|c|c|c|c|c|c|c|c|c|c|c|c|c|}
\hline \multirow[b]{2}{*}{ Component } & \multirow[b]{2}{*}{ Strain } & \multirow{2}{*}{$\begin{array}{c}\text { Growth } \\
\text { temp. . . } \\
\text { Growth } \\
\text { phase . . }\end{array}$} & \multicolumn{2}{|c|}{$50{ }^{\circ} \mathrm{C}$} & \multicolumn{2}{|r|}{$60^{\circ} \mathrm{C}$} & \multicolumn{2}{|c|}{$70^{\circ} \mathrm{C}$} & \multicolumn{2}{|c|}{$75^{\circ} \mathrm{C}$} & \multicolumn{2}{|l|}{$78{ }^{\circ} \mathrm{C}$} \\
\hline & & & Exp. & Sta. & Exp. & Sta. & Exp. & Sta. & Exp. & Sta. & Exp. & Sta. \\
\hline $\begin{array}{l}\text { Total lipid } \\
(\% \text { dry wt) }\end{array}$ & $\begin{array}{l}\text { SPS } 11 \\
\text { SPS } 17\end{array}$ & & $\begin{array}{l}8 \cdot 0 \pm 1 \cdot 1(4) \\
8 \cdot 4 \pm 1.5(2)\end{array}$ & $\begin{array}{l}9.0 \\
9.5\end{array}$ & $\begin{array}{r}8 \cdot 7 \\
10 \cdot 5\end{array}$ & $\begin{array}{r}9 \cdot 7 \\
10 \cdot 2\end{array}$ & $\begin{array}{r}10 \cdot 5 \\
9 \cdot 6\end{array}$ & $\begin{array}{l}9 \cdot 1 \\
9 \cdot 3\end{array}$ & $\begin{array}{r}10.5 \pm 0.7(2) \\
9 \cdot 0 \pm 1 \cdot 2(6)\end{array}$ & $\begin{array}{l}9.9 \pm 3.1(2) \\
9.6 \pm 1.8(2)\end{array}$ & $10 \cdot 4 \pm 1 \cdot 3(2)$ & $\overline{9 \cdot 0}$ \\
\hline $\begin{array}{l}\text { Phosphorus } \\
{\left[10^{2} \times \mu \mathrm{mol}\right.} \\
\left.(\mathrm{mg} \text { dry wt) })^{-1}\right]\end{array}$ & $\begin{array}{l}\text { SPS } 11 \\
\text { SPS } 17\end{array}$ & & $\begin{array}{l}2 \cdot 6 \pm 0.2(5) \\
3 \cdot 0 \pm 0.3(4)\end{array}$ & $\begin{array}{l}2 \cdot 5 \\
2 \cdot 6 \pm 0 \cdot 1(2)\end{array}$ & $\begin{array}{l}2 \cdot 6 \\
2 \cdot 9\end{array}$ & $\begin{array}{l}2.7 \pm 0.1 \text { (2) } \\
3.2 \pm 0.1 \text { (2) }\end{array}$ & $\begin{array}{l}2.5 \\
2.9\end{array}$ & $\begin{array}{l}2 \cdot 6 \\
3 \cdot 1\end{array}$ & $\begin{array}{l}2.7 \pm 0.2(3) \\
2.8 \pm 0.4(6)\end{array}$ & $\begin{array}{l}2 \cdot 5 \pm 0.1(2) \\
2 \cdot 9 \pm 0.1(2)\end{array}$ & $2 \cdot 9 \pm 0.3(2)$ & $\overline{2 \cdot 7}$ \\
\hline $\begin{array}{l}\text { Sugar } \\
{\left[10^{2} \times \mu \mathrm{mol}\right.} \\
\left.(\mathrm{mg} \text { dry wt) })^{-1}\right]\end{array}$ & $\begin{array}{l}\text { SPS } 11 \\
\text { SPS } 17\end{array}$ & & $\begin{array}{l}7.0 \pm 0.9(5) \\
6.5 \pm 0.9(4)\end{array}$ & $\begin{array}{l}5 \cdot 7 \\
6 \cdot 3 \pm 0.8(2)\end{array}$ & $\begin{array}{l}8 \cdot 7 \\
8 \cdot 7\end{array}$ & $\begin{array}{l}6.7 \pm 0.7 \text { (2) } \\
7.2 \pm 0.3(2)\end{array}$ & $\begin{array}{l}8 \cdot 4 \\
9 \cdot 4\end{array}$ & $\begin{array}{l}8 \cdot 5 \\
8 \cdot 3\end{array}$ & $\begin{array}{l}9.9 \pm 1.7(3) \\
8.9 \pm 1.0(6)\end{array}$ & $\begin{array}{l}9.2 \pm 0.9(2) \\
9.7 \pm 0.4(2)\end{array}$ & $10.0 \pm 0.5(2)$ & $\overline{8 \cdot 3}$ \\
\hline $\begin{array}{l}\text { Carotenoids } \\
{\left[10^{2} \times A_{455}\right.} \\
\left.(\mathrm{mg} \text { dry } \mathrm{wt})^{-1}\right]\end{array}$ & $\begin{array}{l}\text { SPS } 11 \\
\text { SPS } 17\end{array}$ & & $\begin{array}{l}0.1 \\
1.2\end{array}$ & $\begin{array}{l}0.1 \\
0.7 \pm 0 \cdot 2(2)\end{array}$ & $\begin{array}{l}0.2 \\
1 \cdot 4\end{array}$ & $\begin{array}{l}0.1 \\
1.2\end{array}$ & $\begin{array}{l}0.1 \\
1.7\end{array}$ & $\begin{array}{l}0.1 \\
1.6\end{array}$ & $\begin{array}{l}0.2 \pm 0.1(2) \\
1.6 \pm 0.3(3)\end{array}$ & $\begin{array}{l}0.1 \\
1.7 \pm 0.1(2)\end{array}$ & $0.8 \pm \overline{0.1}(2)$ & $\overline{1 \cdot 1}$ \\
\hline $\begin{array}{r}\text { Ratio ( } \mu \text { mol lipid sugar)/ } \\
(\mu \text { mol lipid phosphorus })\end{array}$ & $\begin{array}{l}\text { SPS } 11 \\
\text { SPS } 17\end{array}$ & & $\begin{array}{l}2 \cdot 7 \\
2 \cdot 2\end{array}$ & $\begin{array}{l}2 \cdot 3 \\
2 \cdot 4\end{array}$ & $\begin{array}{l}3 \cdot 3 \\
3 \cdot 0\end{array}$ & $\begin{array}{l}2 \cdot 5 \\
2 \cdot 3\end{array}$ & $\begin{array}{l}3 \cdot 4 \\
3 \cdot 2\end{array}$ & $\begin{array}{l}3 \cdot 3 \\
2 \cdot 7\end{array}$ & $\begin{array}{l}3.7 \\
3 \cdot 2\end{array}$ & $\begin{array}{l}3 \cdot 7 \\
3 \cdot 3\end{array}$ & $3.4^{-}$ & $\overline{3 \cdot 0}$ \\
\hline
\end{tabular}


Table 2. $R_{F}$ values for the polar lipids of strains SPS 11 and SPS 17 in two solvent systems and their reactions with $\alpha$-naphthol (carbohydrate), Dittmer-Lester (phosphorus) and ninhydrin (free amino groups) reagents

\begin{tabular}{|c|c|c|c|c|c|}
\hline \multirow[b]{2}{*}{ Lipid } & \multicolumn{2}{|c|}{$R_{F}$ values* } & \multicolumn{3}{|c|}{ Reaction with: } \\
\hline & $\mathbf{A}$ & B & $\alpha$-Naphthol & Dittmer-Lester & Ninhydrin \\
\hline $\mathrm{GL}_{1}$ & 0.06 & 0.24 & + & - & - \\
\hline $\mathrm{GL}_{2}$ & $0 \cdot 19$ & 0.42 & + & - & - \\
\hline $\mathrm{GL}_{3}$ & 0.51 & ND & + & - & - \\
\hline $\mathrm{PL}_{1}$ & 0.25 & 0.50 & - & + & + \\
\hline $\mathrm{PL}_{2}$ & 0.35 & 0.35 & - & + & - \\
\hline $\mathrm{PL}_{3}$ & 0.60 & ND & - & + & - \\
\hline $\mathrm{PL}_{4} \dagger$ & 0.56 & ND & - & + & - \\
\hline
\end{tabular}

ND, Not detected.

* A, Chloroform/methanol/ammonia $(25 \%)$ /water $(70: 30: 4: 1$, by vol.). B, Chloroform/methanol/ water $(65: 25: 4$, by vol.).

$+\mathrm{PL}_{4}$ was detected only in SPS 17 at $78^{\circ} \mathrm{C}$.

extract from both Thermus strains did not vary with the growth temperature or phase of growth. On the other hand, there was an increase in the carbohydrate content of the total lipid extract of both strains; this increase was more pronounced in SPS 17 , which grew at $78^{\circ} \mathrm{C}$. The rise in the carbohydrate content was reflected in an overall increase in the carbohydrate: phosphorus ratio.

The content of carotenoids, as measured by the absorption peak at $455 \mathrm{~nm}$, remained relatively stable throughout the temperature range studied, although there appeared to be a slight increase in the carotenoid content of strain SPS 17 between $60^{\circ} \mathrm{C}$ and $75^{\circ} \mathrm{C}$. No alteration in the absorption spectrum of the carotenoids, between 350 and $600 \mathrm{~nm}$, could be detected within the temperature range.

\section{Effect of growth temperature on the polar lipids and fatty acyl chains}

The separation of the polar lipids from the neutral lipids and carotenoids by TLC with acetone as solvent was rapid and the polar lipid fraction obtained by this method contained, in all cases, over $90 \%$ of the initial lipid phosphorus and carbohydrate in the lipid extract.

The TLC patterns of the polar lipids were similar for both Thermus strains. Three phospholipids and three glycolipids were detected; a fourth phospholipid $\left(\mathrm{PL}_{4}\right)$ was only detected in SPS 17 grown at $78^{\circ} \mathrm{C}$. Phospholipid $1\left(\mathrm{PL}_{1}\right)$ gave a positive ninhydrin reaction in both strains (Table 2). One minor $\alpha$-naphthol-positive lipid co-migrated with a polar carotenoid in all solvent systems used.

Glycolipid $1\left(\mathrm{GL}_{1}\right)$ and phospholipid $2\left(\mathrm{PL}_{2}\right)$ were the major polar lipids in both strains at all the growth temperatures (Table 3 and 4). A rise in the growth temperature from $50{ }^{\circ} \mathrm{C}$ to $78{ }^{\circ} \mathrm{C}$ increased the relative concentration of $\mathrm{GL}_{1}$ in SPS 17 from $87 \%$ to $96 \%$ of the polar lipid carbohydrate, with a concomitant decrease in $\mathrm{GL}_{2}$ from $7-10 \%$ to $1-2 \%$, depending on the growth phase (Table 3). The very minor component, $\mathrm{GL}_{3}$, also decreased as the growth temperature increased (Table 3). In contrast, the relative concentrations of $G_{1}$ and $G_{2} L_{2}$ in strain SPS 11 remained relatively constant over the growth temperature range (Table 4).

The major phospholipid ( $\mathrm{PL}_{2}$ ) decreased in concentration in both strains as the growth temperature increased, whereas $\mathrm{PL}_{1}$ increased in concentration, reaching $19.4 \%$ of the total phosphorus in SPS 17 at $78{ }^{\circ} \mathrm{C}$ (Tables 3 and 4). $\mathrm{PL}_{3}$ appeared to reach its highest concentration in SPS 17 at $70^{\circ} \mathrm{C}$ and $75^{\circ} \mathrm{C}$ during the stationary phase (Table 4). $\mathrm{PL}_{4}$ was detected only at $78^{\circ} \mathrm{C}$ in strain SPS 17 (Table 4).

The major acyl chains in both strains were 13-methyltetradecanoate (iso- $\mathrm{C}_{15}$ ); 12methyltetradecanoate (anteiso- $\mathrm{C}_{15}$ ), 14-methylpentadecanoate (iso- $\mathrm{C}_{16}$ ); 15-methylhexadecanoate (iso- $\mathrm{C}_{17}$ ) and 14-methylhexadecanoate (anteiso- $\mathrm{C}_{17}$ ). An unknown fatty acyl chain reached 
Table 3. Effect of growth temperature and phase of growth on the glycolipid and phospholipid compositions of Thermus SPS 17

Values are given as the percentages of total carbohydrate or phosphorus. Those without error terms are from a single determination; other values are the means \pm SD of the number of experiments indicated in parentheses.

\begin{tabular}{|c|c|c|c|c|c|c|c|c|c|c|c|}
\hline \multirow[b]{2}{*}{ Component } & \multirow{2}{*}{$\begin{array}{c}\text { Growth } \\
\text { temp. . . } \\
\text { Growth } \\
\text { phase ... }\end{array}$} & \multicolumn{2}{|r|}{$50^{\circ} \mathrm{C}$} & \multicolumn{2}{|r|}{$60^{\circ} \mathrm{C}$} & \multicolumn{2}{|c|}{$70^{\circ} \mathrm{C}$} & \multicolumn{2}{|c|}{$75^{\circ} \mathrm{C}$} & \multicolumn{2}{|l|}{$78^{\circ} \mathrm{C}$} \\
\hline & & Exp. & Sta. & Exp. & Sta. & Exp. & Sta. & Exp. & Sta. & Exp. & Sta. \\
\hline $\begin{array}{l}\text { Glycolipids } \\
\text { GL }_{1} \\
\text { GL }_{2} \\
\text { GL }_{3} \\
\text { CA }^{*}\end{array}$ & & $\begin{array}{r}87 \cdot 4 \\
7 \cdot 1 \\
1 \cdot 2 \\
4 \cdot 3\end{array}$ & $\begin{array}{r}87.1 \pm 5.9(2) \\
9.9 \pm 4.4(2) \\
1.2 \pm 0.8(2) \\
1.8 \pm 0.7(2)\end{array}$ & $\begin{array}{r}93.6 \\
5.0 \\
0.5 \\
1.0\end{array}$ & $\begin{array}{l}90 \cdot 0 \pm 1 \cdot 3(2) \\
8 \cdot 3 \pm 3 \cdot 8(2) \\
1 \cdot 3 \\
2 \cdot 1\end{array}$ & $\begin{array}{r}95.8 \\
2.9 \\
0.6 \\
0.7\end{array}$ & $\begin{array}{r}93.4 \\
4.9 \\
0.8 \\
0.8\end{array}$ & $\begin{array}{l}95.7 \pm 0.2(2) \\
2.9 \pm 0.5(2) \\
0.6 \\
1.1 \pm 0.5(2)\end{array}$ & $\begin{array}{l}92.7 \pm 3.8(2) \\
2.2 \\
0.9 \\
1.6 \pm 1.1(2)\end{array}$ & $\begin{array}{r}96 \cdot 4 \\
2 \cdot 1 \\
0.7 \\
0 \cdot 8\end{array}$ & $\begin{array}{r}97.5 \\
1.4 \\
0.4 \\
0.7\end{array}$ \\
\hline $\begin{array}{l}\text { Phospholipids } \\
\text { PL }_{1} \\
\text { PL }_{2} \\
\text { PL }_{3} \\
\text { PL }_{4} \\
\text { Origin }\end{array}$ & & $\begin{array}{r}1.6 \\
95 \cdot 4 \\
1.6 \\
1.5\end{array}$ & $\begin{array}{r}1.7 \pm 0.6(2) \\
96.0 \pm 1.8(2) \\
1.4 \pm 0.7(2) \\
- \\
0.9 \pm 0.6(2)\end{array}$ & $\begin{array}{r}3 \cdot 1 \\
92 \cdot 0 \\
1.5 \\
\frac{2}{3 \cdot 4}\end{array}$ & $\begin{array}{c}1.9 \pm 0.2(2) \\
93.4 \pm 0.5(2) \\
3.2 \pm 0.4(2) \\
- \\
1.5 \pm 0.1(2)\end{array}$ & $\begin{array}{r}5 \cdot 6 \\
91 \cdot 5 \\
0.9 \\
\frac{-}{2 \cdot 1}\end{array}$ & $\begin{array}{r}5 \cdot 5 \\
87 \cdot 2 \\
5 \cdot 3 \\
2 \cdot 0\end{array}$ & $\begin{array}{c}6.7 \pm 0.4(2) \\
90.1 \pm 0.7(2) \\
1.6 \pm 0.2(2) \\
- \\
1.6 \pm 0.1(2)\end{array}$ & $\begin{array}{c}8.9 \pm 0.6(2) \\
84.7 \pm 1.0(2) \\
5.4 \pm 0.1(2) \\
- \\
1.2 \pm 0.6(2)\end{array}$ & $\begin{array}{r}19.4 \pm 0.1(2) \\
75.4 \pm 3.2(2) \\
2.0 \pm 0.6(2) \\
1.2 \pm 0.1(2) \\
2.1 \pm 0.8(2)\end{array}$ & $\begin{array}{r}14 \cdot 3 \\
79 \cdot 1 \\
2 \cdot 1 \\
3 \cdot 0 \\
1.5\end{array}$ \\
\hline
\end{tabular}


Table 4. Effect of growth temperature and phase of growth on the glycolipid and phospholipid compositions of Thermus SPS 11

Refer to Table 3 for details.

\begin{tabular}{|c|c|c|c|c|c|c|c|c|c|}
\hline \multirow[b]{2}{*}{ Component } & \multirow{2}{*}{$\begin{array}{c}\text { Growth } \\
\text { temp. . . } \\
\text { Growth } \\
\text { phase ... }\end{array}$} & \multicolumn{2}{|c|}{$50^{\circ} \mathrm{C}$} & \multicolumn{2}{|r|}{$60^{\circ} \mathrm{C}$} & \multicolumn{2}{|c|}{$70^{\circ} \mathrm{C}$} & \multicolumn{2}{|c|}{$75^{\circ} \mathrm{C}$} \\
\hline & & Exp. & Sta. & Exp. & Sta. & Exp. & Sta. & Exp. & Sta. \\
\hline $\begin{array}{l}\text { Glycolipids } \\
\text { GL }_{1} \\
\text { GL }_{2} \\
\text { GL }_{3} \\
\text { CA }^{*}\end{array}$ & & $\begin{array}{r}93 \cdot 9 \\
4.6 \\
1.4 \\
1.4\end{array}$ & $\begin{array}{r}93 \cdot 6 \\
4.5 \\
0.6 \\
1.3\end{array}$ & $\begin{array}{r}95 \cdot 4 \\
3 \cdot 3 \\
0 \cdot 5 \\
0.8\end{array}$ & $\begin{array}{r}94.7 \pm 0.1 \text { (2) } \\
3.0 \pm 0.3 \text { (2) } \\
0.8 \pm 0.2(2) \\
1.4 \pm 0.3(2)\end{array}$ & $\begin{array}{r}94 \cdot 8 \\
3 \cdot 0 \\
0 \cdot 7 \\
1 \cdot 5\end{array}$ & $\begin{array}{r}95 \cdot 4 \\
3 \cdot 5 \\
0.4 \\
0.6\end{array}$ & $\begin{array}{r}95.6 \pm 1.1 \text { (3) } \\
2.6 \pm 0.7 \text { (3) } \\
0.6 \pm 0.2(3) \\
1.3 \pm 0.7(3)\end{array}$ & $\begin{array}{c}95 \cdot 1 \\
4 \cdot 9 \\
- \\
-\end{array}$ \\
\hline $\begin{array}{l}\text { Phospholipids } \\
\text { PL } \\
\text { PL }_{2} \\
\text { PL }_{3} \\
\text { Origin }\end{array}$ & & $\begin{array}{r}1 \cdot 7 \\
95 \cdot 7 \\
1 \cdot 2 \\
1 \cdot 4\end{array}$ & $\begin{array}{r}0.8 \\
96.9 \\
1.5 \\
0.8\end{array}$ & $\begin{array}{r}2.8 \\
94.4 \\
1.5 \\
1.4\end{array}$ & $\begin{array}{r}2.1 \pm 1.6(2) \\
94.9 \pm 1.7(2) \\
1.7 \pm 0.6(2) \\
1.3 \pm 0.4(2)\end{array}$ & $\begin{array}{r}6 \cdot 4 \\
90 \cdot 7 \\
1 \cdot 2 \\
1 \cdot 7\end{array}$ & $\begin{array}{r}6.0 \\
89 \cdot 7 \\
3 \cdot 0 \\
1 \cdot 3\end{array}$ & $\begin{array}{r}7.8 \pm 0.3(3) \\
89.0 \pm 1.2(3) \\
1.2 \pm 0.4(3) \\
1.2 \pm 0.5(3)\end{array}$ & $\begin{array}{r}7.0 \pm 0.9(2) \\
88.0 \pm 0.7(2) \\
2.3 \pm 0.4(2) \\
2.0 \pm 0.1(2)\end{array}$ \\
\hline
\end{tabular}

Table 5. Effect of growth temperature on the major fatty acid composition of the polar lipids of SPS 11 and SPS 17 in late exponential phase, and the fatty acid composition of $G L_{1}$ at the optimum growth temperature

The values are expressed as a percentage of the total.

\begin{tabular}{|c|c|c|c|c|c|c|}
\hline \multirow{3}{*}{$\begin{array}{l}\text { Fatty } \\
\text { acid }^{*}\end{array}$} & \multicolumn{4}{|c|}{ Polar lipids } & \multicolumn{2}{|c|}{$\mathrm{GL}_{1}$} \\
\hline & \multirow{2}{*}{$\begin{array}{c}\text { Strain ... } \\
\text { Growth } \\
\text { temp. . . . }\end{array}$} & SPS 11 & \multicolumn{2}{|c|}{ SPS 17} & \multirow{2}{*}{$\begin{array}{c}\text { SPS } 11 \\
73^{\circ} \mathrm{C}\end{array}$} & \multirow{2}{*}{$\begin{array}{l}\text { SPS } 17 \\
75^{\circ} \mathrm{C}\end{array}$} \\
\hline & & $73^{\circ} \mathrm{C}$ & $50^{\circ} \mathrm{C}$ & $73^{\circ} \mathrm{C}$ & & \\
\hline $\mathrm{i}-\mathrm{C}_{13}$ & $2 \cdot 72$ & $2 \cdot 84$ & $1 \cdot 86$ & $1 \cdot 30$ & $1 \cdot 12$ & $2 \cdot 34$ \\
\hline UN & ND & 0.83 & ND & ND & ND & ND \\
\hline $\mathrm{i}-\mathrm{C}_{14}$ & 3.48 & 0.54 & $4 \cdot 61$ & 0.76 & 0.75 & 0.58 \\
\hline$n-C_{14}$ & 0.94 & 0.90 & 0.78 & $1 \cdot 16$ & 0.80 & ND \\
\hline $\mathrm{i}-\mathrm{C}_{15}$ & $35 \cdot 11$ & $49 \cdot 42$ & $31 \cdot 23$ & 43.86 & 47.60 & $40 \cdot 18$ \\
\hline$a-C_{15}$ & $12 \cdot 58$ & $6 \cdot 81$ & $14 \cdot 00$ & 6.91 & $6 \cdot 15$ & $6 \cdot 26$ \\
\hline$n-C_{15}$ & $4 \cdot 11$ & 1.79 & 3.43 & $2 \cdot 10$ & $2 \cdot 36$ & 3.03 \\
\hline $\mathrm{i}-\mathrm{C}_{16}$ & $6 \cdot 65$ & $2 \cdot 37$ & $13 \cdot 22$ & $3 \cdot 27$ & $3 \cdot 39$ & 3.61 \\
\hline$a-C_{16}$ & ND & 0.46 & ND & $1 \cdot 14$ & ND & ND \\
\hline UN & 0.31 & ND & $2 \cdot 19$ & ND & ND & ND \\
\hline $\mathrm{n}-\mathrm{C}_{16}$ & 1.39 & 3.67 & $1 \cdot 37$ & 1.61 & $1 \cdot 13$ & 1.09 \\
\hline $\mathrm{i}-\mathrm{C}_{17}$ & $15 \cdot 57$ & $25 \cdot 32$ & 11.04 & $30 \cdot 50$ & $31 \cdot 10$ & 35.89 \\
\hline $\mathrm{a}-\mathrm{C}_{17}$ & 6.89 & $4 \cdot 23$ & $5 \cdot 00$ & 4.96 & 4.44 & $5 \cdot 83$ \\
\hline UN & $6 \cdot 20$ & ND & $7 \cdot 51$ & ND & ND & ND \\
\hline $\mathrm{n}-\mathrm{C}_{17}$ & $3 \cdot 51$ & 0.83 & $2 \cdot 69$ & $1 \cdot 38$ & $1 \cdot 18$ & 1.83 \\
\hline UN & 0.62 & ND & 0.79 & 0.67 & ND & ND \\
\hline
\end{tabular}

ND, not detected.

* UN, Unidentified; i, iso-branched; a, anteiso-branched; n, normal.

fairly high levels $\left(6 \cdot 20-7 \cdot 51 \%\right.$ of the total) in both strains grown at $50{ }^{\circ} \mathrm{C}$, but was not detected at $75^{\circ} \mathrm{C}$. There also appeared to be no preferential distribution of acyl chains in $\mathrm{GL}_{1}$ at the optimum growth temperature (Table 5).

Analysis of the major glycolipids of SPS 11 and SPS 17

The analysis of $\mathrm{GL}_{1}$ of strain SPS 11 indicated a glucose :glucosamine :glycerol : fatty acyl ratio of $2 \cdot 86: 1.01: 1 \cdot 00: 2 \cdot 88$. The molecular proportion of the long-chain fatty acids was determined by GLC. Galactose and galactosamine were not detected by paper chromatography and all the phenol/sulphuric-acid-positive carbohydrate was confirmed as glucose by the glucose 
oxidase method. The presence of amide bands in the infrared spectrum indicated $\mathrm{N}$-acylation of the glucosamine; furthermore the glycolipid gave a negative ninhydrin reaction on TLC. GL 1 of strain SPS 17 proved identical, with a glucose:glucosamine:glycerol:fatty acyl ratio of $2 \cdot 98: 1 \cdot 06: 1 \cdot 00: 2 \cdot 82$.

\section{DISCUSSION}

The total extractable lipid of Thermus sp. strains SPS 11 and SPS 17 increased only slightly as the growth temperature was raised from $50^{\circ} \mathrm{C}$ to 75 or $78^{\circ} \mathrm{C}$, respectively. For $T$. aquaticus strain YT-1 Ray et al. (1971 b) showed a very large increase over the temperature range for growth; nevertheless, the results presented here are in agreement with the values $(8-12 \%$ of the dry weight) reported by Pask-Hughes $\&$ Shaw (1982) at the optimum growth temperature for five strains of Thermus sp. We also failed to detect the increase in phosphorus and carotenoid contents at higher growth temperatures described by Ray et al. $(1971 b)$. In the present study, only an increase in the carbohydrate content was observed with increasing growth temperature.

The polar lipid patterns on TLC, as well as the major phospholipid and major glycolipid contents of strains SPS 11 and SPS 17 agree with the results of Pask-Hughes \& Shaw (1982) and Oshima (1978).

The relative increase in $\mathrm{GL}_{1}$ of strain SPS 17 as the growth temperature was increased was not as pronounced as that in strain HB-8 (Oshima, 1978) and the relative concentration of $\mathrm{GL}_{1}$ of strain SPS 11 was unaffected by the growth temperature.

We have also shown that an increase in the growth temperature caused a decrease in the major phospholipid $\left(\mathrm{PL}_{2}\right)$ and an increase in $\mathrm{PL}_{1}$ of both strains. Similar alterations have been described in other thermophiles such as Bacillus caldotenax (Hasegawa et al., 1980) and Bacillus stearothermophilus (Souza et al., 1974).

The major fatty acyl chains of SPS 11 and SPS 17 proved identical to those described for other Thermus strains (Ray et al., 1971 a; Oshima, 1978; Pask-Hughes \& Shaw, 1982). GL 1 of strain SPS 17 is similar to the major glycolipid of Thermus strain H (Pask-Hughes \& Shaw, 1982), since galactose and/or galactosamine are not present.

This work was supported in part by a grant from the Portuguese Instituto Nacional de Investigação Científica (M.S.C.) and the Spanish Dirección General de Política Científica (A.P.).

\section{REFERENCES}

BARTLETT, G. R. (1959). Phosphorus assay in column chromatography. Journal of Biological Chemistry 234, 466-468.

BLIGH, E. G. \& DYER, W. J. (1959). A rapid method of total lipid extraction and purification. Canadian Journal of Biochemistry and Physiology 37, 911-917.

BoK, S. H. \& Demain, A. L. (1977). An improved colorimetric assay for polyols. Analytical Biochemistry 81, 18-20.

BotTcher, G. J. F., van Gent, C. M. \& Pries, C. (1961). A rapid and sensitive submicro phosphorus determination. Analytica chimica acta 24, 203-204.

BROCK, T. D. (1978). Thermophilic Microorganisms and Life at High Temperatures, pp. 72-91. Edited by M. P. Starr. Berlin: Springer.

BROCK, T. D. \& FreEZE, H. (1969). Thermus aquaticus gen. $n$. and sp. n., a nonsporulating extreme thermophile. Journal of Bacteriology 104, 509-517.

Christie, W. W. (1982). Lipid analysis. Oxford: Pergamon Press.

DitTMER, J. C. \& Wells, M. A. (1969). Quantitative and qualitative analysis of lipids and lipid components. Methods in Enzymology 14, 482-530.
Dubois, M., Gilles, K. A., Hamilton, J. K., Rebers, P. A. \& SMITH, F. (1956). Colorimetric method for determination of sugars and related substances. Analytical Chemistry 28, 350-356.

Hasegawa, Y., Kawada, N. \& Nosoh, Y. (1980). Change in chemical composition of the membrane of Bacillus caldotenax after shifting the growth temperature. Archives of Microbiology 126, 103108.

Hudson, A. J., Morgan, H. W. \& Daniel, R. M. (1986). A numerical classification of some Thermus isolates. Journal of General Microbiology 132, 531540.

Loginova, L. G., Egorova, L. A., Golovacheva, R. S. \& Seregina, L. M. (1984). Thermus ruber sp. nov., nom. rev. International Journal of Systematic Bacteriology 34, 498-499.

Maclean, D. C. \& SCOTT, K. J. (1976). Identification of glucitol (sorbitol) and ribitol in a rust fungus (Puccinia graminis f. sp. tritici). Journal of General Microbiology 97, 83-89.

Oshima, M. (1978). Structure and function of membrane lipids in thermophilic bacteria. In Biochemis- 
try of Thermophily, pp 1-10. Edited by S. M. Friedman. New York: Academic Press.

Oshima, M. \& Yamakawa, T. (1974). Chemical structure of a novel glycolipid from an extreme thermophile, Flavobacterium thermophilum. Biochemistry 13, 1140-1146.

Pask-Hughes, R. A. \& Shaw, N. (1982). Glycolipids from some thermophilic bacteria belonging to the genus Thermus. Journal of Bacteriology 149, 54-58.

Pask-Hughes, R. A. \& Williams, R. A. D. (1977). Yellow-pigmented strains of Thermus spp. from Icelandic hot springs. Journal of General Microbiology 102, 375-383.
RAY, P. H., White, D. C. \& BRoCK, T. D. (1971a). Effect of temperature on the fatty acid composition of Thermus aquaticus. Journal of Bacteriology 106, 2530.

RAY, P. H., White, D. C. \& Brock, T. D. (1971b). Effect of the growth temperature on the lipid composition of Thermus aquaticus. Journal of Bacteriology 108, 221-235.

SouzA, K. A., Kostiw, L. L. \& Tyson, B. J. (1974). Alterations in normal fatty acid composition in a temperature-sensitive mutant of a thermophilic Bacillus. Archives of Microbiology 97, 89-102. 